\title{
A Comparison of Bilateral Decompression via Unilateral Approach and Classic Laminectomy in Patients with Lumbar Spinal Stenosis: A Retrospective Clinical Study
}

\author{
Lomber Dar Kanalı Olan Hastalarda Tek Tarafln Girişimle İki Tarafln \\ Dekompresyonun Klasik Laminektomi ile Karşılaștırılması: \\ Bir Retrospektif Klinik Çalıșma
}

Onur YAMAN ${ }^{1}$, Nail OZDEMIR ${ }^{1}$, Ahmet Turan DAGLI², Erdem ACAR ${ }^{3}$, Sedat DALBAYRAK ${ }^{4}$, Cuneyt TEMIZ

${ }^{1}$ Tepecik Education and Training Hospital, Clinic of Neurosurgery, Izmir, Turkey

${ }^{2}$ Sar Hospital, Clinic of Neurosurgery, Rize, Turkey

${ }_{3}^{3}$ TOBB University of Economics and Technology, Ankara, Turkey

${ }^{4}$ Neurospinal Academy, Department of Neurosurgery, Istanbul, Turkey

${ }^{5}$ Celal Bayar University, School of Medicine, Department of Neurosurgery, Manisa, Turkey

Corresponding Author: OnurYAMAN / E-mail: dronuryaman@yahoo.com

\begin{abstract}
AIM: Bilateral decompression via unilateral approach is one of the minimally invasive methods used for degenerative spinal stenosis. The aim of this retrospective study was to observe the clinical and radiological results of classic laminectomy and bilateral decompression via unilateral approach applied for lumbar stenosis.

MATERIAL and METHODS: The data of 40 patients who underwent surgical treatment for lumbar spinal stenosis with different techniques was reviewed retrospectively. The patients were divided into 2 groups according to the surgical technique. In the first group, patients underwent classic laminectomy, while in the second group patients underwent bilateral decompression via unilateral approach. Preoperative and postoperative computed tomography section areas of both groups were examined. Visual analogue scale (VAS) was used to evaluate low back and leg pain in preoperative and postoperative 1, 6, and 12 months. The two groups were compared in respect of surgery time and bleeding. RESULTS: In both groups, postoperative low back and leg pain VAS scores declined compared to the preoperative condition. Low back pain VAS scores were lower at postoperartive 1, 6, and 12 months. The bleeding was higher in the 1st group, whereas the surgery time was higher in the 2nd group.

CONCLUSION: Bilateral decompression through unilateral approach is an effective method without instability effect, which provides sufficient decompression in the degenerative stenosis and increases patient comfort in the postoperative period.
\end{abstract}

KEYWORDS: Lumbar stenosis, Unilateral approach, Minimally invasive

öz

AMAÇ: Dejeneratif lomber dar kanalda kullanılan minimal invaziv yöntemlerden bir tanesi tek taraflı girişimle iki taraflı dekompresyondur. Bu retrospektif çalışmada, klasik laminektomi ile tek taraflı girişimle iki taraflı dekompresyon sağlanan lomber dar kanal hastalarının klinik ve radyolojik sonuçlarını karşılaştırdık.

YÖNTEM ve GEREÇLER: Lomber stenoz tanısı olan ve farklı tekniklerle opere edilen 40 hastanın verileri retrospektif olarak değerlendirildi. Hastalar uygulanan cerrahi tekniğe göre 2 ayrı gruba ayrıldı. Birinci gruptaki hastalar klasik laminektomi uygulanan hastalar iken, ikinci gruptaki hastalar ise tek taraflı girişimle iki taraflı dekompresyon yapılan olgulardı. Her iki grup için ameliyat öncesi ve sonrası aksiyel bilgisayarlı tomografi görüntüleri elde edildi. Hastaların bel ve bacak ağrıları 1. ayda, 6. ayda ve 12. ayda vizüel analog skalası (VAS) ile değerlendirildi. Her iki grup ameliyat süresi ve kanama miktarı ile de karşılaştırıldı.

BULGULAR: Her iki grupta da ameliyat sonrası bel ve bacak ağrıları için VAS değerlerinde azalma görüldü. ikinci grup için bel ağrısı VAS değerleri 1. ayda, 6 . ayda ve 12. ayda birinci gruba göre düşüktü. Kanama miktarı birinci grupta daha fazlayken ameliyat süresi ikinci grupta daha fazlaydı. SONUÇ: Tek taraflı girişimle iki taraflı dekompresyon lomber dar kanal hastalarında kullanılan minimal invaziv, instabilite yaratmadan yeterli dekompresyon sağlayan ve hastanın cerrahi sonrası memnuniyetini arttıran bir yöntemdir.

ANAHTAR SÖZCÜKLER: Lomber dar kanal, Tek taraflı yaklaşım, Az girişimsel 


\section{INTRODUCTION}

Lumbar spinal stenosis (LSS) is frequently observed in obese patients and the elderly especially due to the aging of the spine. Growth in the facet joints, ligamentum flavum hypertrophy, disc degeneration and osteophytes cause the spinal canal to narrow down, and consequently result in spinal cord and nerve root compression (4). Main symptoms are low back pain, leg pain exacerbated by walking and numbness in legs (25). Surgery must be applied on patients who do not respond to conservative treatment (3). Minimally invasive methods are increasing in number as the technology advances. One of these minimally invasive methods is the bilateral decompression via unilateral approach (27). This study provides a comparative analysis of the clinical and radiological results obtained in classic decompressive laminectomy cases and unilateral approach bilateral decompression cases.

\section{MATERIAL and METHODS}

The data of 40 patients who underwent surgical treatment for degenerative lumbar spinal stenosis without instability was reviewed retrospectively. The patients were divided into 2 groups. Facet joints were protected and classic laminectomy was applied for decompression in patients within group 1 , while patients in the second group underwent bilateral decompression through unilateral approach. In the second group, the intervention was applied either on the disc

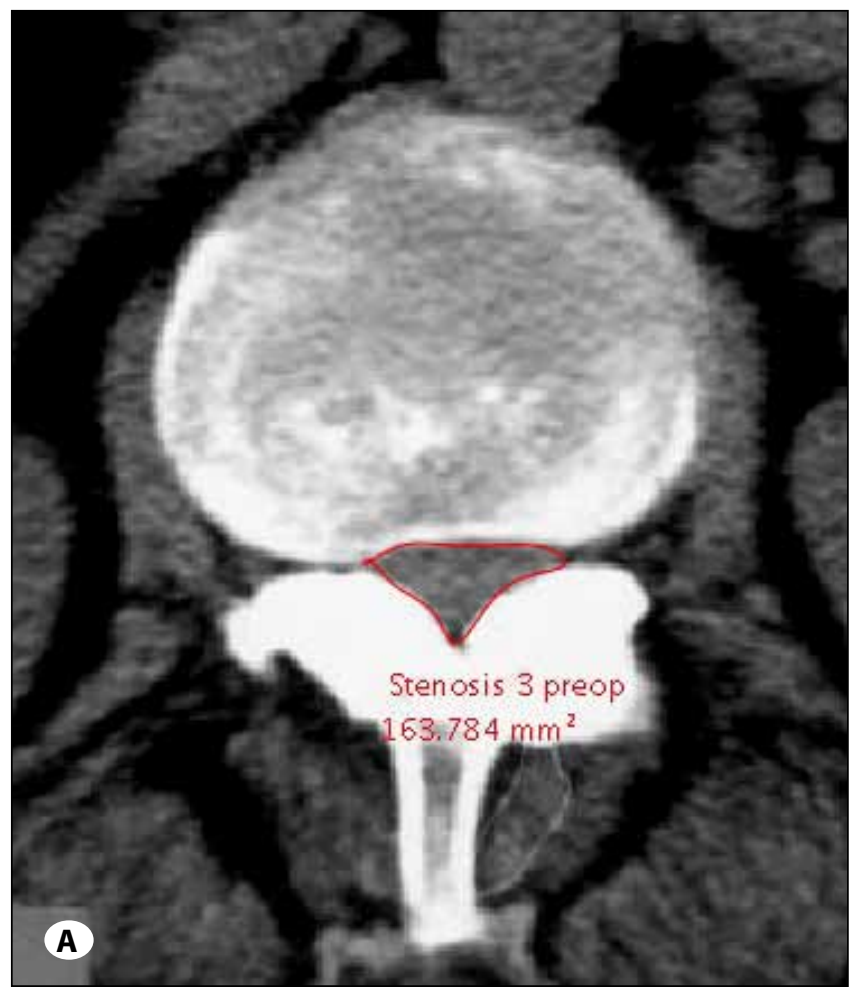

side, if disc was involved, or on the side where leg pain was more severe. If the patient had not reported any specific side, intervention was applied on the right side to facilitate surgeon's performance. Hypertrophic ligamentum flavum was excised using a Kerrison rongeur. Later the operating table was positioned contralaterally and microscope angle was modified to face the contralateral side. Contralateral ligamentum flavum was also excised, and contralateral foraminotomy was performed to provide decompression.

Patients' low back and leg pain were evaluated by using Visual Analogue Scale (VAS) score in pre-op and post-op months 1, 6 and 12. An osseous spinal canal view was obtained using computerized axial tomography (CAT) sections in pre-op and post-op stages (Surgimap). The two groups were compared in respect of surgery time, bleeding and complications.

\section{Bilateral Decompression Surgery via Unilateral Approach:}

The patient under the general anaesthesia is placed on the operating table in prone position. After level determination via fluoroscopy, paravertebral muscles are stripped either on the disc side, if the disc is involved, or on the right side of the patient. After performing hemilaminectomy and flavectomy, the operating table is positioned contralaterally and microscope angle is modified to face the contralateral side. Using the high-speed burr and fine Kerrison rongeurs, contralateral laminectomy and flavectomy are applied under the spinous process, and the surgical operation is concluded after contralateral foraminotomy (Figure 1A,B, 2A,B).

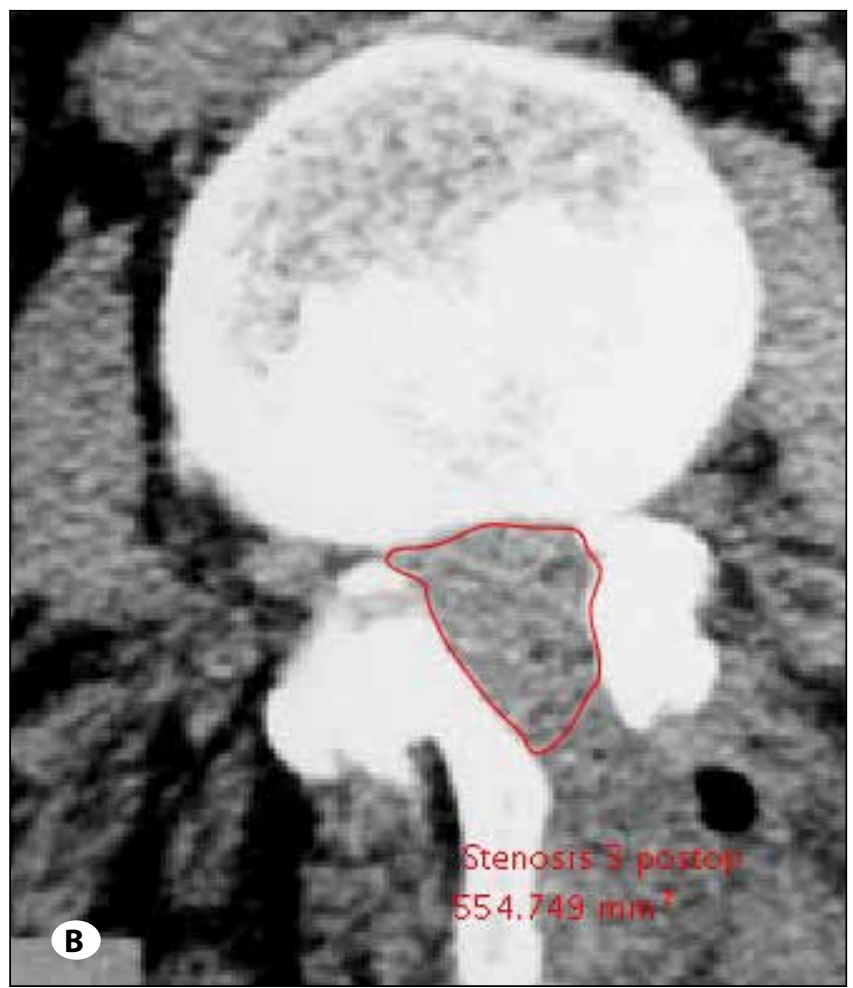

Figure 1: A) Pre-operative CAT (computerized axial tomography) section of patient 3. B) Post-operative CAT (computerized axial tomography) section of patient 3 . 

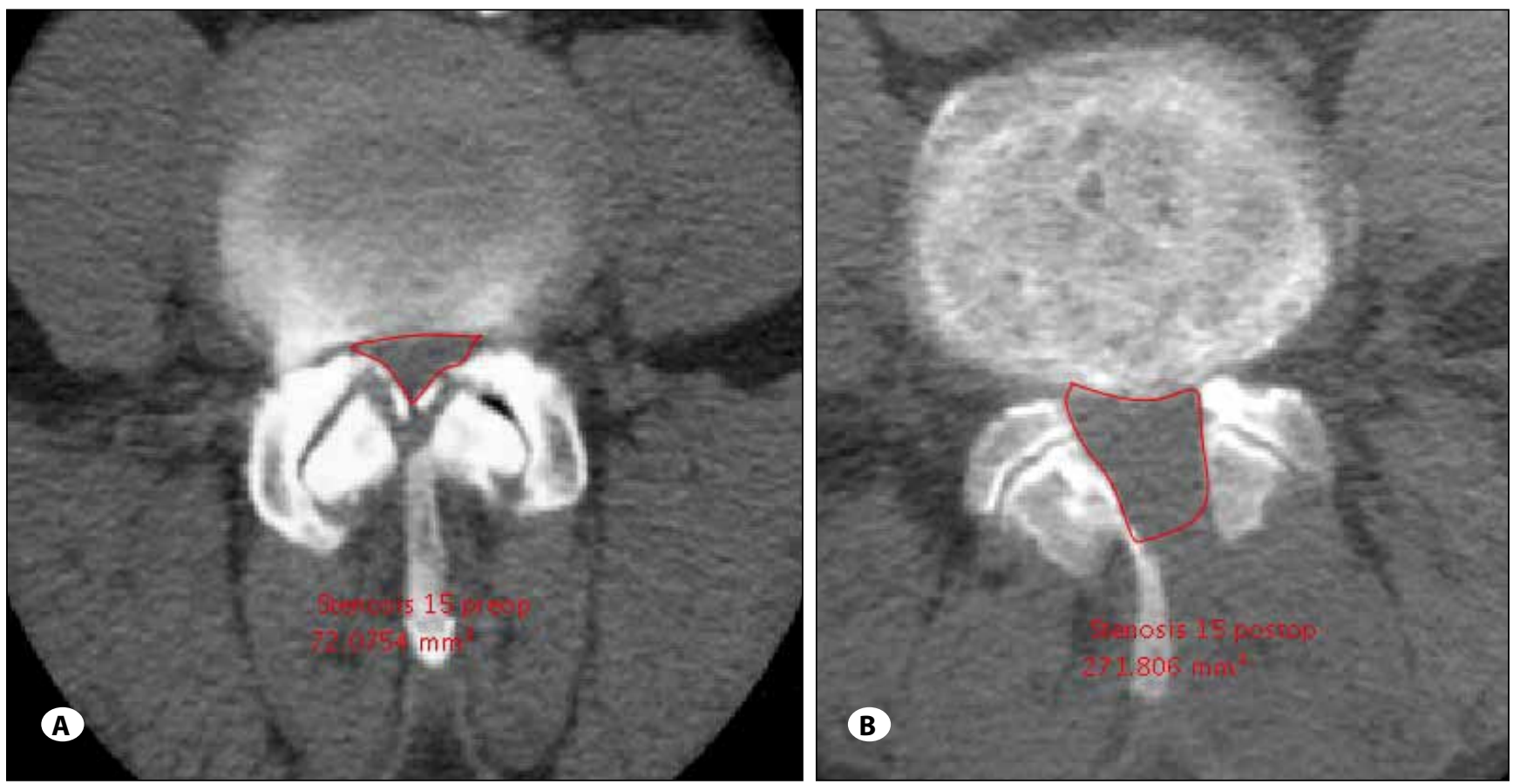

Figure 2: A) Pre-operative CAT (computerized axial tomography) section of patient 15. B) Post-operative CAT (computerized axial tomography) section of patient 15 .

\section{RESULTS}

The age of patient population varied between 45 and 74, while the average age was found to be 60 .

The patients showed symptoms of low back pain, leg pain, numbness in legs and urinary incontinence.

\section{Pain Levels}

For patients in group 1, pre-op low back pain mean VAS score was $8.11 \pm 0.85$, whereas the VAS score was recorded as 4.08 \pm 0.81 at month $1,3.33 \pm 0.59$ at month 6 , and $2.25 \pm 0.60$ at month 12 during the post-operative stage. For patients in group 2, pre-op low back pain mean VAS score was $8.03 \pm 0.73$, whereas the VAS score was recorded as $2.03 \pm 0.48$ at month 1 , and as $1.73 \pm 0.51$ at month 6 during the post-operative stage. Checks at post-op month 12 revealed an average VAS score of $1.35 \pm 0.48$.

For patients in group 1, pre-op leg pain VAS score was $7 \pm$ 0.63 , whereas the VAS score was recorded as $2.06 \pm 0.23$ at post-op month 1. Average VAS scores were recorded as $1.86 \pm$ 0.35 at post-op months 6 and $1.75 \pm 0.44$ at post-op months 12. In unilateral approach bilateral decompression patients, pre-op VAS score was $8.00 \pm 0.60$, whereas the score declined to $2.78 \pm 0.53$ in post-op month 1 and to $1.88 \pm 0.52$ at postop months 6 and to $1.78 \pm 0.62$ at post-op months 12 .

When the leg pain VAS scores were compared group 1 had significantly lower scores at the first month (Student's t-test, $p<0.001$ ). But the difference were not significantly at the month 6 and 12 .
Group 2 had significantly lower low back pain VAS scores, particularly at month 1, at month 6 and at month 12, compared with Group 1. (Student's t-test, $p<0.001$; Wilcoxon signed-rank test, $p<0.05)$.

\section{Pathology Levels}

Decompression levels in the first group were L4-5 (47.2\%), L3-4 (41.6\%), L2-3 (8.3\%), L5-S1 (2.7\%) totally 36 levels. In the second group, decompression was applied to 40 levels. L4-5 (60.0\%), L3-4 (32.5\%), L2-3 (7.5\%), respectively (Table I).

\section{Complications}

There were three durotomies in the first and two durotomies in the second group that were primarily repaired. The intergroup difference was not statistically significant. We had no other complication.

\section{Surgery Time}

In group 1, surgery time per level was minimum 35, maximum 50 minutes, while the average was 44.7 minutes. In group 2, average surgery time per level was 59.4 minutes (minimum 50, maximum 70 minutes). Mean surgery time for classic laminectomy was less than the group 2. The intergroup difference was found to be statistically significant (Student's t-test, $p<0,001$; Wilcoxon signed-rank test, $p<0,05)$. Surgery times for each group are shown in Figure 3.

\section{Amount of Bleeding}

Average amount of blood lost per level was 238 cc in group 1 (minimum $200 \mathrm{cc}$, maximum $300 \mathrm{cc}$ ), while average bleeding was $90 \mathrm{cc}$ in group 2, with minimum $50 \mathrm{cc}$ and maximum 150 
cc. Amount of blood lost was higher for classical laminectomy than bilateral laminectomy via unilateral approach. (Student's t-test, $p<0,001$; Wilcoxon signed-rank test, $p<0,05$ ). Amount of blood lost are shown in Figure 4.

Table I: Levels and Numbers Distributed According to Groups

\begin{tabular}{|l|r|r|r|r|} 
& \multicolumn{2}{|c|}{ Group 1 } & \multicolumn{2}{c|}{ Group 2 } \\
\hline Level & Number & Ratio & Number & Ratio \\
\hline L2-3 & 3 & $8.3 \%$ & 3 & $7.5 \%$ \\
\hline L3-4 & 15 & $41.6 \%$ & 13 & $32.5 \%$ \\
\hline L4-5 & 17 & $47.2 \%$ & 24 & $60.0 \%$ \\
\hline L5-S1 & 1 & $2.7 \%$ & 0 & $0 \%$ \\
\hline Total & 36 & $100 \%$ & 40 & $100 \%$ \\
\hline
\end{tabular}

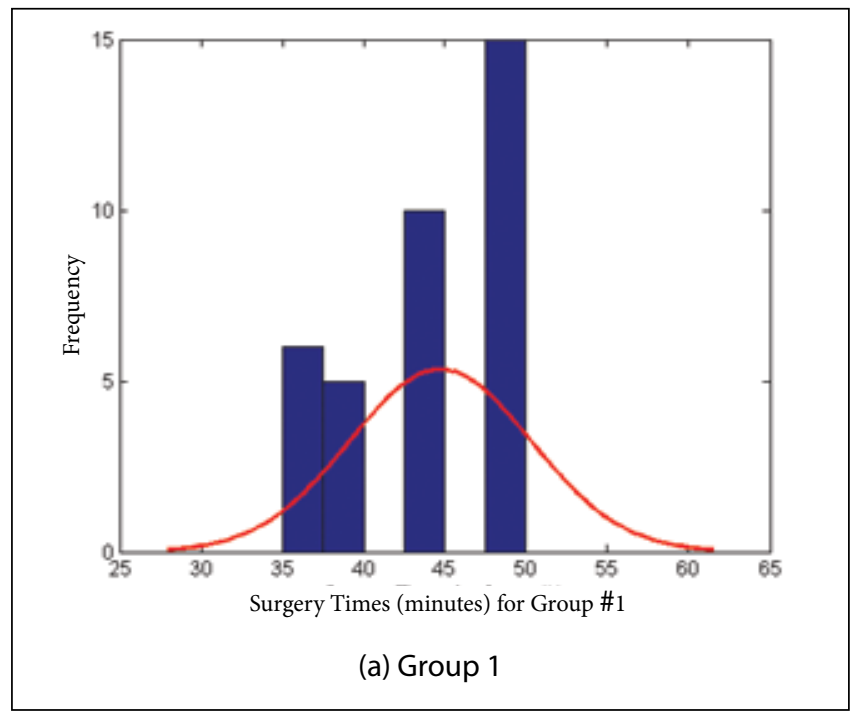

Figure 3: Surgery times for each group.

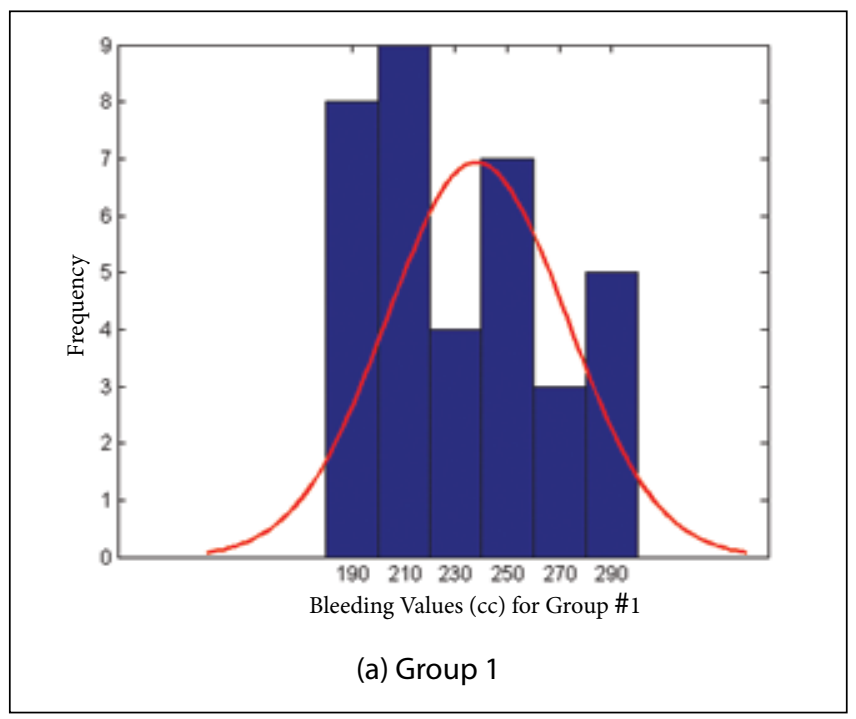

Figure 4: Amount of blood lost for each group.

\section{Computerized Axial Tomography (CAT) Sections}

In group 1 with classic laminectomy decompression, preop computerized axial tomography sections indicated an average of $114.3 \mathrm{~mm}^{2}$ area (minimum: 64, Maximum: 170 $\mathrm{mm}^{2}$ ). Standard deviation was 29.3. In group 2 with unilateral approach bilateral decompression, pre-op computerized axial tomography sections indicated an average of $120.4 \mathrm{~mm}^{2}$ (minimum $72 \mathrm{~mm}^{2}$, maximum $197 \mathrm{~mm}^{2}$ ), standard deviation was 30.6. The intergroup difference was not statistically significant (Student's t-test; $p>0.05$ ) (Figure 5).

The average area of computerized axial tomography (CAT) increased to $407.7 \mathrm{~mm}^{2}$ in the post-op stage (minimum $280 \mathrm{~mm}^{2}$, maximum $535 \mathrm{~mm}^{2}$ ) for the patients in group 1. While the average area of CAT increased to $391.1 \mathrm{~mm}^{2}$ in the post-op stage (minimum $240 \mathrm{~mm}^{2}$, maximum $554 \mathrm{~mm}^{2}$ ).
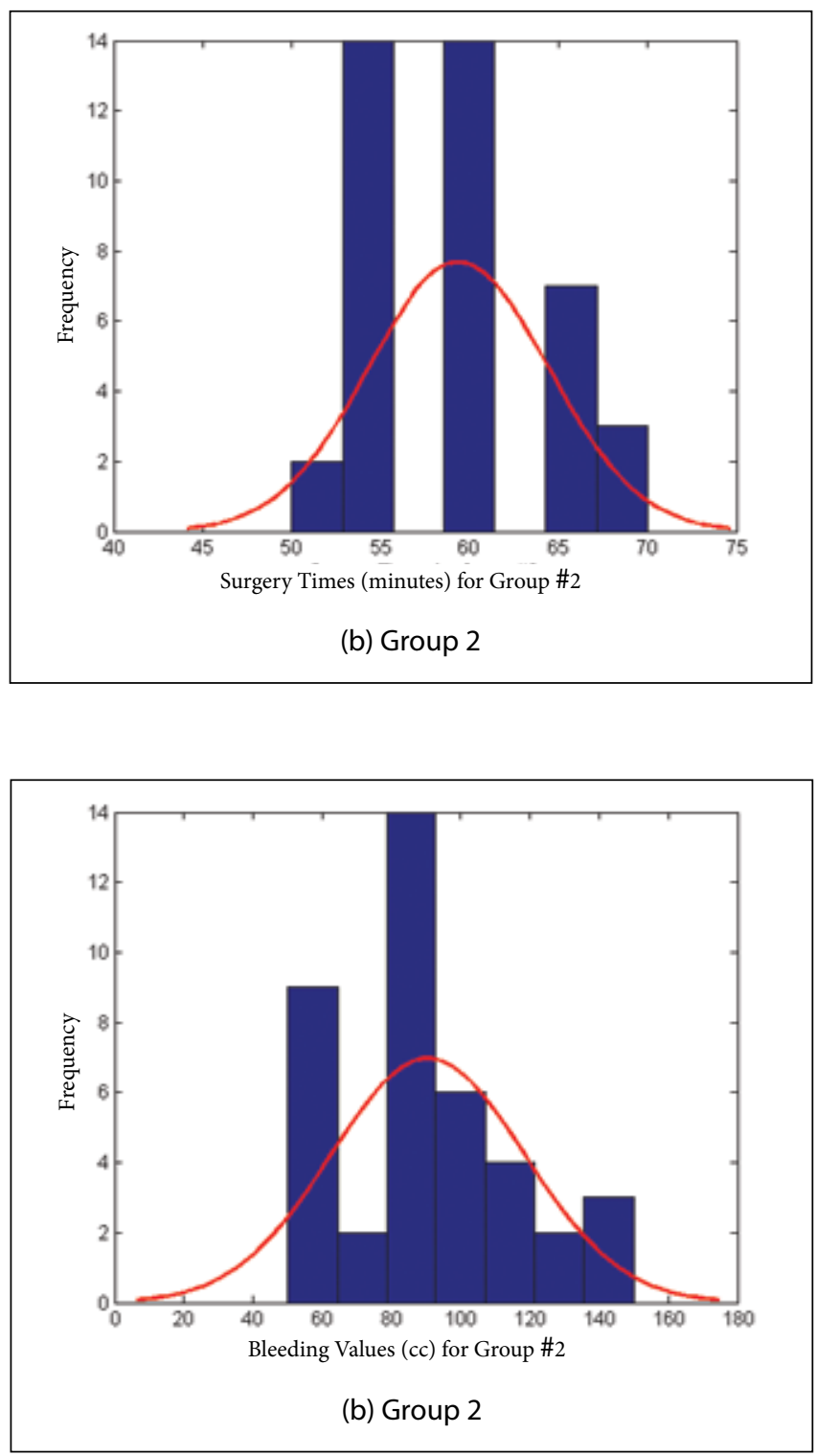


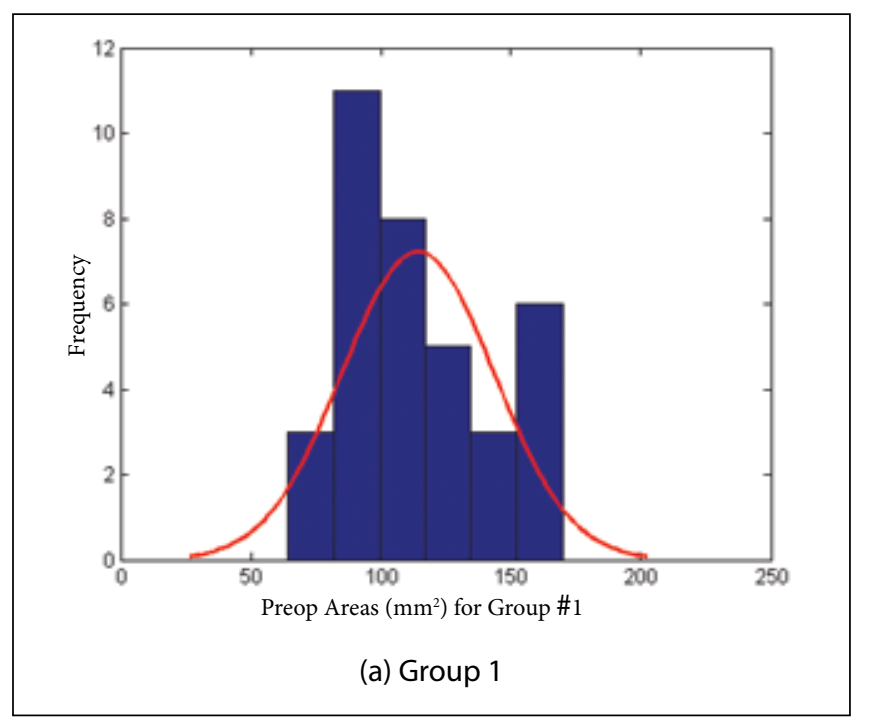

Figure 5: Spinal area in Pre-op CAT sections for each group.

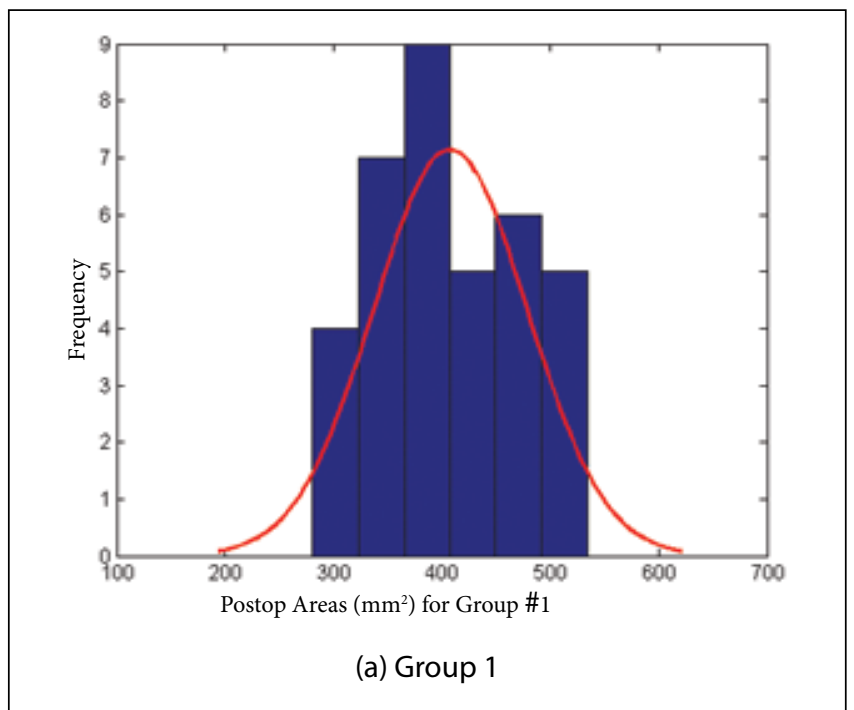

Figure 6: Spinal area in Post-op CAT sections for each group.

The intergroup difference was not statistically significant (Student's t-test; $p>0.05$ ) (Figure 6).

\section{DISCUSSION}

There might be various reasons for spinal stenosis, but the most common reason is due to degenerative process. Degenerative spinal stenosis is more frequently observed in the older population of age 60 and above (24). The process that is initiated with the disc degeneration causes growth in facet joints and hypertrophy of the ligamentum flavum, which is then concluded with posterior longitudinal ligament thickening (20). One or several of the above mentioned factors cause decrease in the diameter of spinal canal, which results in compression of the spinal cord or nerve roots (25). Degenerative spinal stenosis is most frequently observed in
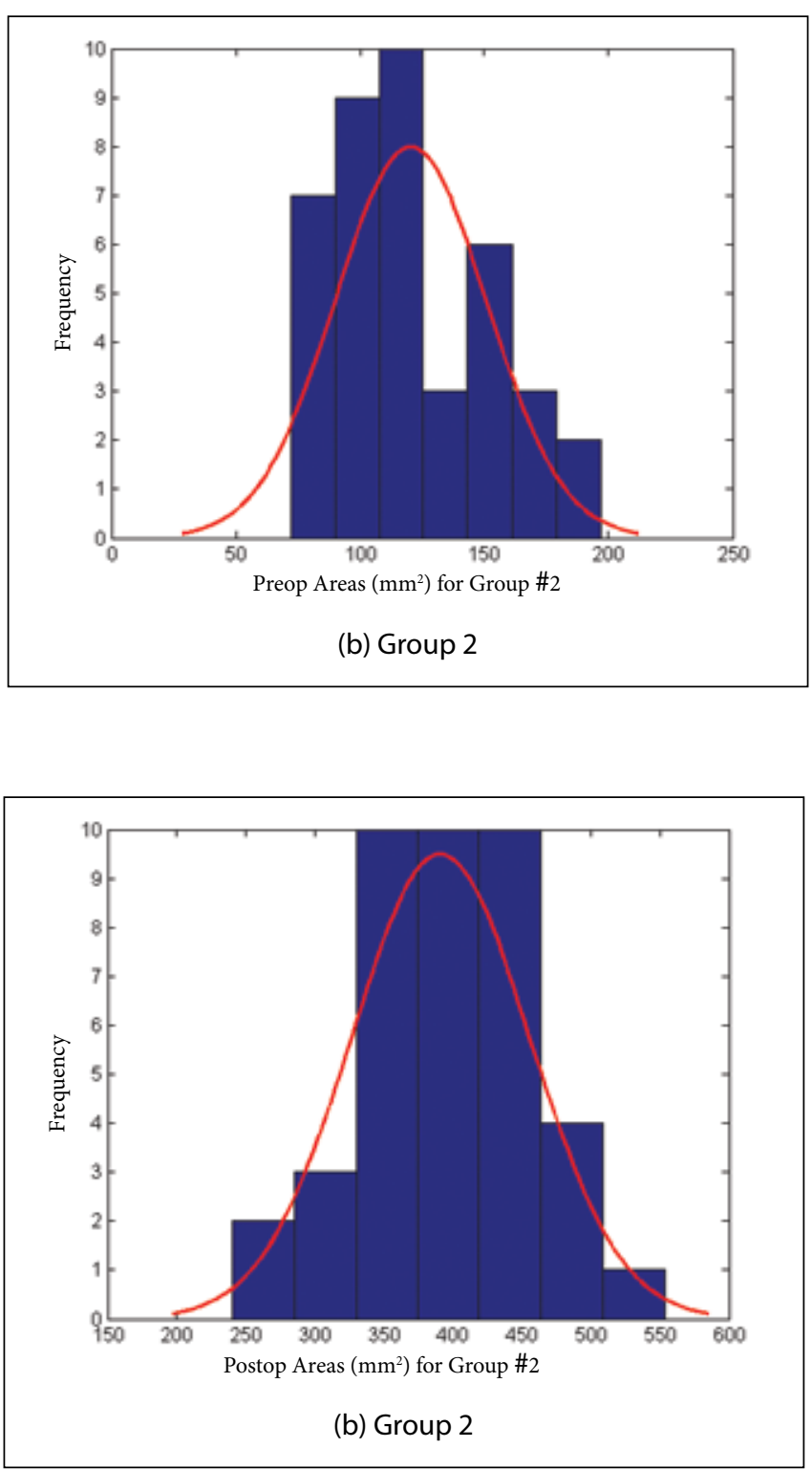

the L4-L5 (11). Microcirculation in nerve roots is damaged due to compression. The most common symptoms are numbness in legs, weakness and leg pain that emerges while walking. The pain is defined as neurogenic claudication, and it gets intensified in case of walking or extension. The pain reduces while the patient is resting or bending forward (28).

Different imaging techniques can be used to define the spinal canal stenosis; myelography, CT myelography, CT and MRI. Different measurements were reported in the literature: Transverse and antero-posterior diameter of the osseous spinal canal, ligamentous interfacet distance $(13,26)$. One of the most effective diagnosis methods in spinal stenosis is the computerized tomography. Spinal canal diameter and area can be measured through CT. We measured the osseos spinal canal area in CT. 
Surgical treatment should be planned for patients with progressive loss of strength and no response to conservative treatment. Surgery aims at eliminating the stenosis through increasing the spinal canal diameter (15). Wide bilateral total laminectomy and partial or complete facetectomy are performed in the conventional surgical treatment of spinal stenosis $(5,7)$. This has been very effective for improvement of clinical symptoms but this conventional surgical intervention causes the complete elimination of posterior column, which has a role in the stabilization $(2,16,19)$. Radiographic evidence of progression of spondylolisthesis was present if greater than $50 \%$ of the facet joint was resected at any one level (1). Biomechanical studies showed the clinical importance of maintaining an intact posterior tension band and facet joints. The supraspinous ligament supported the greatest load to flexion forces in cadaver models (9). Also Hindle et al. demonstrated significant loading forces absorbed by the supraspinous and interspinous ligaments during flexion forces (14). Hasegawa et al. mentioned the biomechanical effects preserving the posterior structures following minimally invasive decompression for lumbar spinal canal stenosis and revealed the muscle-preserving interlaminar decompression superiority (12). Postoperative spinal instability has always been a major concern after laminectomy and in the preoperative spondylolisthesis cases may lead to the iatrogenic spinal instability in higher rates. Minimally invasive approaches are becoming more important to avoid postoperative instability $(8,10,27)$.

Minimalization is a general trend in spine surgery. Due to developments in diagnostic imaging there has been a great evolution in minimally invasive surgical techniques for the spinal surgery. Minimally invasive techniques for degenerative diseases, trauma, deformities and malignancies had been described as an alternative to conventional approaches (22). Less incisional pain, earlier ambulation, shorter hospital stays are the main advantages of minimally invasive approaches $(21,23)$

Bilateraldecompressionviaunilateralapproachisanalternative minimally invasive approach for classical laminectomy. The patient is placed on the operating table in prone position under the general anaesthesia. After level determination via fluoroscopy, paravertebral muscles are stripped either on the disc side, if the disc is involved, if not on the right side of the patient is preferred. After performing hemilaminectomy and flavectomy, the operating table is positioned contralaterally and microscope angle is modified to face the contralateral side. Using the high-speed burr and Kerrison rongeurs, contralateral laminectomy and flavectomy are applied under the spinous process, and the surgical operation is concluded after contralateral foraminotomy. During classic decompressive laminectomy, wider sub-periosteal stripping of the paravertebral muscles and wider bone resection, result in post-op low back pain. Recent researches showed that atrophy of multifidus muscles may relate to damage to the dorsal rami of the posterior branches caused by extensive muscle stripping. In the two years follow-up results of Liu et al. showed that the atrophy rate of multifidus cross sectional areas and postoperative VAS of low back pain were lower in the group that underwent bilateral decompression via unilateral approach than the group underwent conventional laminectomy (18). Patients operated with the conventional method (group 1) displayed significantly higher low back pain VAS scores in post-op months 1, 6, 12 compared to patients in group 2, who underwent bilateral decompression via unilateral approach. As regards the leg pain, the two groups displayed no significant difference at the months 6 and 12. But group 1 had lower VAS leg pain scores at the first month. Patients with wide resection suffer from higher intraoperative blood loss. Krutko mentioned that blood loss was higher in the group that underwent bilateral decompression via unilateral approach for lumbar spinal stenosis than the group that underwent standart technique (17). In our study significant difference was observed in the comparative analysis of the blood loss of two groups. Some patients in group 1 required red blood cell transfusion, whereas there were no patients requiring transfusion in group 2 .

There were three durotomies in the first and two durotomies in the second group that were primarily repaired. When the complication rates were compared the difference wasn't statistically significant. All dural tears were in the older patients but bilateral decompression via unilateral approach does not carry extra risk in elderly population (6). Krut'ko investigated less complication in the group that underwent bilateral decompression via unilateral approach for lumbar spinal stenosis than the group that underwent standard technique (17).

Comparative pre-op and post-op analysis indicated significant increase in computerized axial tomography section areas in both groups. However, the groups did not display any significant differences. Comparison of both area measurements and post-op leg pain VAS scores indicate no significant differences, which reveals that sufficient decompression was ensured in bilateral decompression via unilateral approach.

In terms of surgery time, conventional procedure applied to group 1 was observed to be shorter, whereas the unilateral approach bilateral decompression required significantly longer surgery time. It was observed that operating table and microscope adjustments for contralateral flavectomy and foraminotomy required longer time in group 2. The use of fine Kerrison rongeurs contributed to the longer surgery time. To avoid complications, which might be caused by the high-speed burr, the surgeon had to act more diligently. Especially in patients with no reported side or disc, righthanded surgeons could easily work from the right side for contralateral foraminotomy. Although longer surgery time seems like a disadvantage compared to the classic procedure, surgery time in unilateral approach bilateral decompression has been observed to decline as the surgeon improves in his learning curve. 


\section{CONCLUSION}

Bilateral decompression through unilateral intervention is an effective method with no instability effect, which provides sufficient decompression in the degenerative stenosis and increases patient comfort in the post-operative stage.

\section{REFERENCES}

1. Abumi K, Panjabi MM, Kramer KM, Duranceau J, Oxland T, Crisco JJ: Biomechanical evaluation of lumbar spinal stability after graded facetectomies. Spine 15(11):1142-1147, 1990

2. Adams MA, Hutton WC: The mechanic function of the lumbar apophyseal joints. Spine (Phila Pa 1976) 8: 327-330, 1983

3. Amundsen $T$, Weber $H$, Lilleås $F$, Nordal $H J$, Abdelnoor $M$, Magnaes $B$ : Lumbar spinal stenosis: Clinical and radiologic features. Spine 20:1178-1186, 1995

4. Arbit E, Pannullo S: Lumbar stenosis: A clinical review. Clin Orthop 384:137-143, 2001

5. Daubs MD, Lenke LG, Bridwell KH, Cheh G, Yongjung JK, Stobbs G: Decompression alone versus decompression with limited fusion for treatment of degenerative lumbar scoliosis in the elderly patient. Evid Based Spine Care J 3(4):27-32, 2012

6. Deschuyffeleer S, Leijseen P, Bellemans J: Unilateral laminotomy with bilateral decompression for lumbar stenosis: Short term risks in elderly individuals. Acta Orthop Belg 78(5): 672-677, 2012

7. Epstein NE, Epstein JE: Lumbar decompression for spinal stenosis. The adult spine: Principles and practice. Frymoyer JW (ed). Philadelphia: Lippincott-Raven, 1997:2055-2088

8. Fager C: Comments to: Relief of lumbar canal stenosis using multilevel subarticular fenestrations as an alternative to wide laminectomy: Preliminary report. Neurosurgery 23:63, 1988

9. Goel VK, Fromknecht SJ, Nishiyama K: The role of lumbar spinal elements in flexion. Spine 10(6):516-523, 1985

10. Guiot BH, Khoo LT, Fesler RG: A minimal invasive technique for decompression of the lumbar spine. Spine 27(4): 432-438, 2002

11. Haba K, Ikeda M, Soma M, Yamashima T: Bilateral decompression of multilevel lumbar spinal stenosis through a unilateral approach. Journal of Clinical Neuroscience 12(2):169-171, 2005

12. Hasegawa K, Kitahara K, Shimoda H, Hara T: Biomechanical evaluation of destabilization following minimally invasive decompression for lumbar spinal canal stenosis. J Neurosurg Spine 18(5): 504-510, 2013

13. Herzog RJ, Kaiser JA, Saal JA, Saal JS: The importance of posterior epidural fat in lumbar central canal stenosis. Spine (Phil Pa 1976) 16(6 suppl): S227-233, 1991
14. Hindle RJ, Pearcy MJ, Cross A: Mechanical function the human lumbar interspinous and supraspinous ligaments. Journal of Biomedical Engineering 12(4):340-344, 1990

15. Iguchi T, Kurihara A, Nakayama J, Sato K, Kurosaka M, Yamasaki K: Minimum 10-year outcome of decompressive laminectomy for degenerative lumbar spinal stenosis. Spine $25: 1754-1759,2000$

16. Lee CK: Lumbar spinal instability (olisthesis) after extensive posterior spinal decompression. Spine 8(4):429-433, 1983

17. Krut'ko AV: Results of decompressive-stabilizing procedures via unilateral approach in lumbar spinal stenosis. Zh Vopr Neirokhir Im N N Burdenko 76(2):33-40; discussion 40-41, 2012

18. Liu X, Yuan S, Tian Y: Modified unilateral laminotomy for bilateral decompression for lumbar spinal stenosis-technical note. Spine (Phila Pa 1976) 38(12):E732-E737, 2013

19. Mullin BB, Rea GL, Irsik R, Catton M, Miner ME: The effect of postlaminectomy spinal instability on the outcome of lumbar spinal stenosis patients. J Spinal Disord 9: 107-116, 1996

20. Postacchini F: Management of lumbar spinal stenosis. J Bone Joint Surg 78:154-164, 1996

21. Rosenthal D, Rosenthal $R$, Desimone A: Removal of a protruded thoracic disc using microsurgical endoscopy. A new technique. Spine 19:1087-1091, 1994

22. Sarioglu AC, Hancı M, Bozkus H, Kaynar M, Kafadar A: Unilateral hemilaminectomy for the removal of the spinal space-occupying lesions. Minim Invasive Neurosurgery 40(2):74-77, 1997

23. Sasani M, Ozer AF, Oktenoglu T, Kaner T, Aydin S, Canbulat N, Carilli S, Sarioglu AC: Thoracoscopic surgical approaches for treating various thoracic spinal region diseases. Turk Neurosurg 20(3): 373-381, 2010

24. Schmidek H: Operative neurosurgical techniques: Indications, methods and results. 4th ed. Massachusetts: Saunders Company, 2000: 2207-2217

25. Sirvanci $M$, Bhatia $M$, Ganiyusufoglu KA, Duran C, Tezer M, Ozturk C, Aydogan M, Hamzaoglu A: Degenerative lumbar spinal stenosis: Correlation with oswestry disability index and MR imaging. Eur Spine J 17:679-685, 2008

26. Steurer J, Roner S, Grannt R, Hodler J: Quantitative radiologic criteria for the diagnosis of lumbar spinal stenosis: A systemic literature review. BMC Musculoskeletal Disorders 12:175,2011

27. Yang B, Chen R, Xie P, Liu B, Dong J, Rong L: Microendoscopic decompression via unilateral approach for lumbar spinal stenosis. Zhongguo Xiu Fu Chong Jian Wai Ke Za Zhi 25(10):1158-1163, 2011

28. Zileli M, Ozer F: Omurilik ve Omurga Cerrahisi, Volume 1. İzmir: Meta Basım Matbaacılık Hizmetleri, 2002: 739-746 